\title{
Fipronil residual content in the soil for the control of Oryzophagus oryzae in subsequent flooded rice crops
}

\author{
José Francisco da Silva Martins ${ }^{(1)}$, Maria Laura Turino Mattos ${ }^{(1)}$, \\ Fernando Felisberto da Silva( ${ }^{(2)}$ and Germano Tessmer Büttow ${ }^{(3)}$
}

\begin{abstract}
(1)EmbrapaClimaTemperado,RodoviaBR-392,Km78,CaixaPostal403,CEP96010-971 Pelotas, RS,Brazil.E-mail:jose.martins@embrapa.br, maria.laura@embrapa.br (2)Universidade Federal do Pampa, Rua Luiz Joaquim de Sá Britto, s/no, CEP 97650-000 Itaqui, RS, Brazil. E-mail: fernando.silva@unipampa.edu.br (3)Universidade Federal de Pelotas, Faculdade de Agronomia Eliseu Maciel, Departamento de Fitossanidade, Campus Universitário, s/no, Caixa Postal 354, CEP 96010-900 Pelotas, RS, Brazil. E-mail: germanotbuttow@hotmail.com
\end{abstract}

\begin{abstract}
The objective of this work was to evaluate the potential of fipronil (a.i.) residual content in the soil of flooded rice fields, for the control of Oryzophagus oryzae (Coleoptera: Curculionidae) in subsequent rice cultivations. In 2010/2011, plots $(25 \times 55 \mathrm{~m})$ were installed with three treatments: 30 g fipronil (a.i.) $100 \mathrm{~kg}^{-1}$ seed; mixture of $1 / 3$ treated seed (30 g fipronil $100 \mathrm{~kg}^{-1}$ seed) with $2 / 3$ untreated seed equivalent to $10 \mathrm{~g}$ fipronil (a.i.) $100 \mathrm{~kg}^{-1}$ seed; and a control without insecticide application. The plots were regrown in 2011/2012, 2012/2013, and 2013/2014 without any insecticide application. The following variables were evaluated: number of larvae and adults from standard samples of soil and roots, and grain yield. In 2011/2012 and 2012/2013, the concentrations of fipronil and of its residues in the soil of plots were evaluated by liquid chromatography and mass spectrometry, and the metabolite fipronil-sulfide $\left(\leq 1.1 \mu \mathrm{g} \mathrm{kg}^{-1}\right)$ was detected. In the three seasons, after the use of seeds treated with 10 and $30 \mathrm{~g}$ fipronil, the average larval infestation of $O$. oryzae was 65.2 and $96.1 \%$ lower, and the average of rice grain yield was 16.9 and $25.5 \%$ higher than in the control plot, respectively. The residual fipronil content in the soil, mainly of the highest dose, effectively controls the insect.

Index terms: Oryza sativa, fipronil-sulfide, insecticide, rice water weevil.

\section{Teor residual de fipronil no solo para o controle de Oryzophagus oryzae em cultivos subsequentes de arroz irrigado}

\begin{abstract}
Resumo - O objetivo deste trabalho foi avaliar o potencial do teor residual de fipronil (i.a.), em solo de arroz irrigado por inundação, para o controle de Oryzophagus oryzae (Coleoptera: Curculionidae), em cultivos subsequentes. Em 2010/2011, instalaram-se talhões (25x55 m) com três tratamentos: $30 \mathrm{~g}$ de fipronil (i.a.) $100 \mathrm{~kg}^{-1}$ de sementes; mistura de $1 / 3$ de sementes tratadas ( $30 \mathrm{~g}$ de fipronil $100 \mathrm{~kg}^{-1} \mathrm{de}$ sementes) com $2 / 3 \mathrm{de}$ sementes não tratadas equivalentes a $10 \mathrm{~g}$ de fipronil (i.a.) $100 \mathrm{~kg}^{-1}$ de sementes; e testemunha sem inseticida. Os talhões foram replantados em 2011/2012, 2012/2013 e 2013/2014 sem qualquer aplicação de inseticida. Avaliaram-se as seguintes variáveis: número de larvas e adultos, emergentes de amostras-padrão de solo e raízes, e produção de grãos. Em 2011/2012 e 2012/2013, avaliaram-se as concentrações de fipronil e de seus resíduos no solo dos talhões, por meio de cromatografia líquida e espectrofotometria de massa, tendo-se detectado o metabólito fipronil-sulfeto $\left(\leq 1,1 \mu \mathrm{g} \mathrm{kg}^{-1}\right)$. Nas três safras, após o uso de sementes tratadas com 10 e $30 \mathrm{~g}$ de fipronil, a infestação larval média de $O$. oryzae foi 65,2 e $96,1 \%$ menor, e a produtividade média do arroz 16,9 e $25,5 \%$ maior do que no talhão testemunha, respectivamente. $O$ teor residual de fipronil no solo principalmente o da maior dose, controla eficazmente o inseto.
\end{abstract}

Termos para indexação: Oryza sativa, fipronil-sulfeto, inseticida, gorgulho-aquático.

\section{Introduction}

Oryzophagus oryzae (Costa Lima) (Coleoptera: Curculionidae) is a highly damaging insect to rice fields in Southern Brazil, where more than $80 \%$ of this crop is cultivated in flooded system (Acompanhamento..., 2015). Known as rice water weevil, O. oryzae hibernates in its adult phase in native plants and plant waste, inside and around rice fields (Martins \& Cunha, 2015). With the increasing temperature and photoperiod (Mielitz et al., 1996), and the beginning of crop flooding in the spring, adults leave the hibernation sites by short flights and, predominantly, through irrigation water, and invade the rice fields from September to 
December, feeding on rice leaves. O. oryzae oviposit on the submerged parts of leaf sheaths, close to the upper limit of irrigation water, and its larvae - known as rootworms for feeding on rice roots - hatch about ten days after oviposition. In the $2^{\text {nd }}$ instar, larvae penetrate the soil up to $6 \mathrm{~cm}$ depth (Neves et al., 2011), they can entirely prune roots (Eberhardt et al., 2015), and reduce rice yield by about $20 \%$ (Martins \& Cunha, 2015). In the state of Rio Grande do Sul, at least two annual generations of $O$. oryzae occur in rice fields. Although some practices of rice crop management reduce the adult population and larvae of $O$. oryzae (Gomes \& Magalhães Júnior), the predominant control measure in Rio Grande do Sul is seed treatment with fipronil (pyrazole chemical group) that acts by contact and ingestion. This active ingredient has been applied in excess and, for each crop, the cultivated area with treated seed is estimated in 650,000 ha (Martins \& Cunha, 2015).

However, there is potential to reduce the fipronil amount in the control of $O$. oryzae. Althought the recommended dose of this insecticide is 30 to

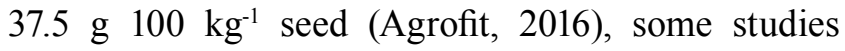
show that only $1 / 3$ of the smallest registered dose, equivalent to $10 \mathrm{~g}$ fipronil $100 \mathrm{~kg}^{-1}$ seed, is enough for an effective control (Martins et al., 2010), and may reduce rice production costs and risks of environmental contamination. In soils of flooded rice cultivations, fipronil photodegradation generates fipronil-desulfinyl (Ngim \& Crosby, 2001). Fipronil-sulfone and fipronilsulfide are generated under aerobic (by oxidation) and anaerobic (by reduction) conditions, respectively (Doran et al., 2009). These metabolites have low mobility in the soil, can reach up to $15 \mathrm{~cm}$ depth (Tingle et al., 2000), and persist for long periods (Bonmatin et al., 2015). In some situations, these metabolites are much more toxic than the original active ingredient (Cox, 2005).

Fipronil and its metabolites may accumulate in the soil and in sediments of rice fields (Bedient et al., 2005; Mattos et al., 2008), as well as in adjacent rivers (Marchesan et al., 2010), harming several aquatic organisms (Cox, 2005; Jinguji et al., 2013; Manrique et al., 2013). In a carciniculture in flooded rice fields in Louisiana, USA, fipronil residues from seed treatment for the control of rice water weevil (Lissorhoptrus oryzophilus Kuschel) have caused damages to crayfish Procambarus clarkii Girard (Schlenk et al., 2001).
The objective of this work was to evaluate the potential of fipronil (a.i.) residual content in the soil of flooded rice fields, for the control of Oryzophagus oryzae (Coleoptera: Curculionidae) in subsequent rice cultivations.

\section{Materials and Methods}

The experiment was carried out in four crop seasons (from 2010/2011 to 2013/2014), in a Planossolo Háplico (Typic Albaqualf), at Embrapa Clima Temperado, in Capão do Leão, at 31\%48'45"S and $52^{\circ} 27^{\prime} 59^{\prime \prime} \mathrm{W}$, in the state of Rio Grande do Sul, Brazil. The area has a history of $O$. oryzae occurrence, and it has never been cultivated with seed treated with fipronil a.i. On October 21, 2010 (2010/2011 crop season), three adjacent plots $(25 \times 55 \mathrm{~m})$ were installed with the rice 'BRS Querência', in an uniform soil (no slope), in a completely randomized design. This experimental model was chosen due to soil uniformity (flat surface), which is essential for the formation of an irrigation water depth of the same thickness in the three plots, with uniform distribution of $O$. oryzae adults.

Each plot received one of the following treatments: the minimum registered dose for the control of O. oryzae, equal to $30 \mathrm{~g}$ fipronil (a.i.) $100 \mathrm{~kg}^{-1}$ seed; a mixture of $1 / 3$ of treated seed ( $30 \mathrm{~g}$ fipronil $100 \mathrm{~kg}^{-1}$ seed) with $2 / 3$ of untreated seed, equivalent to the approximate dose of $10 \mathrm{~g}$ fipronil (a.i.) $100 \mathrm{~kg}^{-1}$ seed, according to Martins et al. (2010); and a control treatment without insecticide application.

Seed were treated 18 hours before the mechanized sowing (density $90 \mathrm{~kg}$ seed ha ${ }^{-1}$ ), in spaced rows in the soil that was plowed 20 days before the conventional cultivation. The other agronomic practices were applied according to technical procedures for rice culture (Gomes \& Magalhães Júnior, 2004), excluding, however, the use of insecticides.

The plots, isolated by levees, were flooded 23 days after the emergence of rice seedlings with a $15 \mathrm{~cm}$ water depth. The larval infestation level of $O$. oryzae was evaluated 30 and 48 days after flooding, in standard samples of soil and roots, which were collected and examined according to Neves et al. (2011). The first assessment occurred when five larvae per sample were detected in the control plot, which is established as the economic damage level (threshold) caused by $O$. oryzae (Martins \& Cunha, 2015). In 
each assessment, two samples were collected from 15 equidistant points on the diagonal line of each plot, and each point was considered as a repeat.

At 48 days after flooding, two more samples of soil and roots were collected from each sampling point to count the adults (weevils) that developed and emerged from the roots, according to the methodology of Martins et al. (2001). These samples, kept intact with stem parts $(20 \mathrm{~cm})$ on the top, were submerged $10 \mathrm{~cm}$ in water, inside plastic buckets covered by a screen fabric. The counts, which began 10 days after sample submersions, continued at 2 to 3-day intervals, during 35 days, at higher temperature schedules, when emerged adults moved to the edge of the buckets.

In the crop seasons 2011/2012, 2012/2013, and 2013/2014, the agronomic practices for rice, and the count methodology for larvae and adults of $O$. oryzae were equal to those adopted in 2010/2011. However, seed used in the three plots were not treated with the insecticide. There were changes only for sowing dates - November 9, 2011, November 26, 2012, and November 30, 2013 - and respective flooding dates (21, 18, and 19 days, after seedling emergences), larval counts ( 27 and 49, 52 and 87, and 50 and 85 days after flooding), and adult counts (starting 59, 62, and 50 days after flooding). Rice grain yield was estimated by the harvests at nine equidistant areas $(2 \times 4 \mathrm{~m})$ from each plot, considering each area as a repeat.

In 2011/2012 and 2012/2013, for the analysis of residual fipronil, fipronil-sulfide and fipronil-sulfone, soil samples were collected between the rice rows at $5 \mathrm{~cm}$ deth, through a section of PVC pipe $(5 \mathrm{~cm}$ diameter), in five equidistant points in each plot. From each point, three subsamples were taken to form a composite sample. In 2011/2012, this sampling was performed 25 days after the initial count of $O$. oryzae larvae, in order to identify possible residual effects of fipronil on the insects, from the 2010/2011 crop season, which justified the chemical analyses. In 2012/2013, soil samples were collected 20 days after flooding the plots. Immediately after collection, the samples were frozen until analysis by liquid chromatography and mass spectrometry (LC-MS/MS) according to AOAC International (2007) - in a lab with official accreditation (Bioensaios, 2016). The soil samples were collected in the second (February 04, 2012) and third (January 10, 2013) rice crop seasons, respectively at 470 and 810 days after the first rice sowing (in 2010/2011), when seed treated with fipronil were used.

For the statistical analysis, the program Assistat (Silva \& Azevedo, 2002) was used, and the normality of the previously obtained data was checked by the Shapiro-Wilk test. The number of larvae and adults of O. oryzae (x) was normalized by the transformation into $(\mathrm{x}+0.5)$ square root. These variables and rice grain weight (without transformation) were subjected to two types of analysis of variance: the joint analysis of the four crop seasons, comparing the effect of rice seed treatment with fipronil (2010/2011) to the effects detected in the three crop seasons without using insecticide (2011/2012 to 2013/2014); and the joint analysis of the three crop seasons without using insecticide. Based on the significance of the F test, the means were compared by the Scott-Knott test, at 5\% probability. The relationship between the emergence level of adults and grain weight was analyzed with the larval infestation level, by correlating the means of the treatments in the four crop seasons $[\mathrm{N}=12$, $\mathrm{t}$ test $(\mathrm{p} \leq 0.01)]$.

\section{Results and Discussion}

In 2010/2011 and in the tree subsequent rice growing seasons, the level of larval infestation of $O$. oryzae in the control plot - with seed without fipronil treatment - was about 3-5 times higher than that of the economic damage threshold level of five larvae per sample, established for this insect (Martins \& Cunha, 2015). In 2010/2011 and 2011/2012, this level was reached at about 30 days after flooding; however, in 2012/2013 and 2013/2014, it was reached only later, about 50 days after flooding. Possibly, this occurred because, in the $3^{\text {rd }}$ and $4^{\text {th }}$ crop seasons, rice was sown in late November, which allowed plants to get free of the $1^{\text {st }}$ larval generation (November-December). Plants would have been infested, then, by the $2^{\text {nd }}$ generation of larvae, which occurred from February to March (Martins, 1976). Displacements of infestation, however, were not shown in the results of the experiment, since in 2012/2013 and 2013/2014, the level of larval infestation in the control plot was respectively higher than and equal to the detected levels in the previous crop seasons. In the four crop seasons, larval infestation in the control plot was significantly higher than in plots with treated seed (Table 1). 
The management practices - basically the cleaning of irrigation structures and the destruction of stubble - applied to the experimental area after harvesting are antagonistic to the survival of adults of O. oryzae (Gomes \& Magalhães Júnior, 2004). In this case, the detected larvae in the plots may have originated predominantly from the oviposition of adults that migrated from hibernation sites outside the experimental area (Mielitz et al., 1996). Therefore, in a paddy field, it is less likely for a larval infestation level significantly lower to reflect in a smaller autochthonous population of adults (derived from seed treatment) that remained in the same area in the off-season.

In 2010/2011, the larval infestation levels of O. oryzae, in plots with fipronil (a.i.) at $10 \mathrm{~g} 100 \mathrm{~kg}^{-1}$

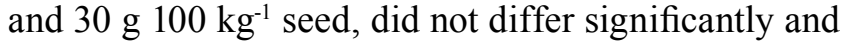
reached a high control effectiveness (Table 1). This confirms previous results (Martins et al., 2010) that even the dose at $10 \mathrm{~g}$ of the insecticide, equivalent to $1 / 3$ of the minimum registered dose (Agrofit, 2016), effectively controls the insect.

In 2011/2012, 2012/2013, and 2013/2014, when no insecticide was applied to rice seed, the larval infestation levels of $O$. oryzae in the plot with treated seed with $30 \mathrm{~g}$ fipronil did not differ significantly from the level detected in the first crop season (2010/2011), and the high control efficiency was kept (Table 1). However, in the plot with seed treated with $10 \mathrm{~g}$ fipronil, from 2011/2012 onward, larval infestation was significantly higher, which showed a loss of the toxic effect of the treatment.

The significantly lower levels of larval infestation of O. oryzae, which were kept in 2011/2012,2012/2013, and $2013 / 2014$, in the pre-cultivated plots with seed treated with $10 \mathrm{~g}$ and $30 \mathrm{~g}$ fipronil (Table 1), probably resulted from the insecticide effect on the insects, related to fipronil residues in the soil. This inference is based on the detection of fipronil-sulfide at concentrations above the limit of quantification $\left(0.5 \mu \mathrm{g} \mathrm{kg}^{-1}\right)$ up to 470 days (2011/2012) and 810 days (2012/2013) in the soil of the cultivated plots with seed treated respectively with 10 and $30 \mathrm{~g}$ of fipronil $100 \mathrm{~kg}^{-1}$ seed in 2010/2011 (Table 2). Fipronil-sulfide and other metabolites derived from degradation of fipronil insecticide, when reach an average concentration in the soil of $1 \mu \mathrm{g} \mathrm{kg}^{-1}$ above the limit of detection, may exert deleterious effects on

Table 1. Number \pm standard error of Oryzophagus oryzae larvae per standard sample of soil and roots, collected in flooded rice plots cultivated in the first crop season (2010/2011) with seed treated with fipronil, and three subsequent crop seasons without insecticide application ${ }^{(1)}$.

\begin{tabular}{|c|c|c|c|c|c|c|c|c|c|c|}
\hline \multirow[t]{3}{*}{ Treatment $^{(2)}$} & \multirow{2}{*}{\multicolumn{2}{|c|}{$\begin{array}{c}\text { Treated seed } \\
2010 / 2011 \\
\end{array}$}} & \multicolumn{8}{|c|}{ Seed and plant not treated with insecticide } \\
\hline & & & \multicolumn{2}{|c|}{$2011 / 2012$} & \multicolumn{2}{|c|}{$2012 / 2013$} & \multicolumn{2}{|c|}{$2013 / 2014$} & \multicolumn{2}{|c|}{ Means $^{(3)}$} \\
\hline & No. of larvae & $\mathrm{CE}^{(4)}(\%)$ & No. of larvae & CE (\%) & No. of larvae & $\mathrm{CE}(\%)$ & No. of larvae & $\mathrm{CE}(\%)$ & No. of larvae & CE (\%) \\
\hline Control & $14.3 \pm 1.5 \mathrm{aB}$ & - & $15.9 \pm 1.7 \mathrm{aB}$ & - & $23.3 \pm 1.9 \mathrm{aA}$ & - & $15.0 \pm 3.5 \mathrm{aB}$ & - & $18.1 \pm 2.6 \mathrm{a}$ & - \\
\hline Fipronil 10 & $1.7 \pm 0.4 \mathrm{bB}$ & 88.1 & $5.4 \pm 0.8 \mathrm{bA}$ & 60.3 & $7.1 \pm 1.0 \mathrm{bA}$ & 69.5 & $6.4 \pm 0.8 \mathrm{bA}$ & 57.3 & $6.3 \pm 0.9 \mathrm{~b}$ & 65.2 \\
\hline Fipronil 30 & $0.4 \pm 0.1 \mathrm{bA}$ & 97.2 & $0.7 \pm 0.2 \mathrm{cA}$ & 91.2 & $0.1 \pm 0.1 \mathrm{cA}$ & 99.6 & $1.2 \pm 0.5 \mathrm{cA}$ & 92.0 & $0.7 \pm 1.1 \mathrm{c}$ & 96.1 \\
\hline
\end{tabular}

${ }^{(1)}$ Means followed by equal letters, lowercase in the columns and uppercase in the rows, do not differ by the Scott-Knott test, at $5 \%$ probability. ${ }^{(2)}$ Equivalent to $10 \mathrm{~g}$ (fipronil 10) and equal to $30 \mathrm{~g}$ (fipronil 30) $100 \mathrm{~kg}^{-1}$ seed. ${ }^{(3)}$ Means of crop seasons without insecticide application. ${ }^{(4)} \mathrm{CE}$, control efficiency according to Abbott (1925).

Table 2. Fipronil residues ( $\mu \mathrm{g} \mathrm{kg}^{-1}$ ) in the soil of flooded rice plots, cultivated in 2010/2011 with seed treated with this insecticide for the control of Oryzophagus oryzae, and in two subsequent crop seasons without insecticide application to seed and plants.

\begin{tabular}{lccccccc}
\hline Treatment $^{(1)}$ & \multicolumn{3}{c}{$2011 / 2012^{(2)}$} & & \multicolumn{3}{c}{$2012 / 2013^{(2)}$} \\
\cline { 2 - 3 } & Fipronil $^{(3)}$ original & Fipronil-sulfide $^{(3)}$ & Fipronil-sulfone $^{(3)}$ & & Fipronil original & Fipronil-sulfide & Fipronil-sulfone \\
\hline Control & $\mathrm{ND}^{(4)}$ & $\mathrm{ND}$ & $\mathrm{ND}$ & & $\mathrm{ND}$ & ND & ND \\
Fipronil 10 & $\mathrm{ND}$ & 1.28 & $\mathrm{ND}$ & $\mathrm{ND}$ & 0.37 & ND \\
Fipronil 30 & $\mathrm{ND}$ & $\mathrm{ND}$ & $\mathrm{ND}$ & 1.10 & ND \\
\hline
\end{tabular}

${ }^{(1)}$ Equivalent to $10 \mathrm{~g}$ (fipronil 10) and equal to $30 \mathrm{~g}$ (fipronil 30) $100 \mathrm{~kg}^{-1}$ seed. ${ }^{(2)}$ Without insecticide application, and analysis of residues in the soil samples, respectively at 470 and 810 days after sowing in 2010/2011 with treated seed. ${ }^{\left({ }^{3}\right)}$ Quantification limits (LOQ): fipronil original $=0.2 \mu \mathrm{g} \mathrm{kg}{ }^{-1}$; fipronil-sulfone $=0.4 \mu \mathrm{g} \mathrm{kg}^{-1}$; and fipronil-sulfide $=0.5 \mu \mathrm{g} \mathrm{kg}^{-1}$. ${ }^{(4)}$ Nondetected. 
crayfish Procambarus clarkii, in case of the future use of rice areas for rearing this crustacean (Bedient et al., 2005). Therefore, fipronil-sulfide detected above the limit of quantification (Table 2) may also have exerted a similar toxic effect on $O$. oryzae in the three crop seasons following 2010/2011.

The fact that fipronil-sulfide was the only residue detected (Table 2) is attributed to a fast reductive degradation of fipronil, and to the strong sorption to the soil under anaerobic conditions, which is common in flooded areas (Doran et al., 2009). As fipronilsulfide was detected in the crop seasons 2011/2012 and 2012/2013, it is inferred that the management practices applied to the experimental area - mainly the harrowing (pre-sowing and post-harvest) and the continuous plot flooding - created favorable edaphic conditions for this metabolite permanence in the soil. The harrowing tends to stir the soil at less than $15 \mathrm{~cm}$ depth (Gomes \& Magalhães Júnior, 2004), as deep as this metabolite type can be adsorbed (Tingle et al., 2000) and remain with low mobility (Raveton et al., 2007). The continuous flooding, without leaks, possibly maintained the highest content of fipronil-sulfide in the soil. Thus, the fipronil-sulfide potential to control $O$. oryzae in subsequent rice crop seasons is evident, since it is more frequent and durable in flooded soils, and about as twice as toxic to aquatic organisms than fipronil (Fipronil, 1996). This can make it unnecessary to apply insecticides on rice seed and plants, which would reduce the production costs.

$O$. oryzae adults may have been contaminated themselves directly with fipronil (from the original application), in the 2010/2011 crop season, when treated seed were used, as insecticide residues would have risen from the soil to the irrigation water, despite the low-to-moderate persistence in this medium
(Ngim \& Crosby, 2001). In the three following crop seasons (untreated seed), the probability of adults to be contaminated by irrigation water was lower because the insecticide had been degraded already in fipronilsulfide (Doran et al., 2009) adsorbed in the soil (Tingle et al., 2000). In this case, other effects of fipronil or its metabolites on adult insects, such as repellency, would hardly occur. There are indications that fipronil volatilization is ineffective in water (Ngim \& Crosby, 2001), and that, when sprayed, it remains volatile only for a short time (Bonmatin et al., 2015). Thus, the main deleterious effects on $O$. oryzae, detected in the last three crop seasons, resulted from direct contamination of larvae by fipronil-sulfide concentrated in the rhizosphere, which may have acted by contact or ingestion (Agrofit, 2016).

The risk of environmental contamination by fipronil may be decreased if, for the control of $O$. oryzae, the dose of this insecticide applied do rice seed $\left(30 \mathrm{~g} 100 \mathrm{~kg}^{-1}\right.$ seed) is $70 \%$ reduced (Martins et al., 2010). In addition, there is potential to use the insecticide residual content in the soil, even that of the dose equivalent to $10 \mathrm{~g}$ $100 \mathrm{~kg}^{-1}$ seed, evidenced in the present study. Given the possibility of not using chemical control of $O$. oryzae in rice fields pre-cultivated with fipronil treated seed, in the first sowing, the option for a smaller or larger dose of the insecticide should be based in the history of the insect occurrence in the area to be cultivated.

The rate of emergence of $O$. oryzae adults from rice roots, in the four rice growing seasons (Table 3), was proportional to larval infestation (Figure $1 \mathrm{~A}$ ). The joint analysis of the number of adults emergence, in three crop seasons without the use of the insecticide, showed a lower control efficiency of these insects in the plot initially cultivated (2010/2011) with seed treated with $10 \mathrm{~g}$ fipronil $100 \mathrm{~kg}^{-1}$ seed (Table 3). However, the

Table 3. Number \pm standard error of Oryzophagus oryzae adults that emerged per standard sample of soil and roots, collected in flooded rice plots cultivated in the first crop season (2010/2011) with seed treated with fipronil, and in three subsequent crop seasons without insecticide application ${ }^{(1)}$.

\begin{tabular}{|c|c|c|c|c|c|c|c|c|c|c|}
\hline \multirow[t]{3}{*}{ Treatment $^{(2)}$} & \multirow{2}{*}{\multicolumn{2}{|c|}{$\begin{array}{c}\text { Treated seed } \\
2010 / 2011\end{array}$}} & \multicolumn{8}{|c|}{ Seed and plants not treated with insecticide } \\
\hline & & & \multicolumn{2}{|c|}{$2011 / 2012$} & \multicolumn{2}{|c|}{$2012 / 2013$} & \multicolumn{2}{|c|}{$2013 / 2014$} & \multicolumn{2}{|c|}{ Mean $^{(3)}$} \\
\hline & No. of adults & $\mathrm{CE}^{(4)}(\%)$ & No. of adults & $\mathrm{CE}(\%)$ & No. of adults & $\mathrm{CE}(\%)$ & No. of adults & $\mathrm{CE}(\%)$ & No. of adults & CE $(\%)$ \\
\hline Control & $12.0 \pm 1.0 \mathrm{aB}$ & - & $14.3 \pm 0.7 \mathrm{aB}$ & - & $29.1 \pm 6.1 \mathrm{aA}$ & - & $6.7 \pm 1.2 \mathrm{aC}$ & - & $16.7 \pm 4.3 \mathrm{a}$ & - \\
\hline Fipronil 10 & $0.3 \pm 0.1 \mathrm{bB}$ & 97.6 & $4.0 \pm 0.4 \mathrm{bB}$ & 72.2 & $9.7 \pm 1.9 \mathrm{bA}$ & 66.7 & $1.6 \pm 0.4 \mathrm{aB}$ & 76.2 & $5.1 \pm 1.4 b$ & 69.5 \\
\hline Fipronil 30 & $0.2 \pm 0.1 \mathrm{bA}$ & 98.4 & $0.7 \pm 0.2 \mathrm{bA}$ & 95.1 & $0.2 \pm 0.1 \mathrm{cA}$ & 99.3 & $1.1 \pm 0.4 \mathrm{aA}$ & 83.6 & $0.7 \pm 1.5 \mathrm{c}$ & 95.8 \\
\hline
\end{tabular}

(1) Means followed by equal letters, lowercase in the columns and uppercase in the rows, do not differ by the Scott-Knott test, at $5 \%$ probability. ${ }^{(2)}$ Equivalent to $10 \mathrm{~g}$ (fipronil 10) and equal to $30 \mathrm{~g}$ (fipronil 30) $100 \mathrm{~kg}^{-1}$ seed. ${ }^{(3)}$ Means of crop seasons without insecticide application. ${ }^{(4)} \mathrm{CE}$, control efficiency according to Abbott (1925). 
possible harmful additional effects of residues to the biology of insects which emerge were not evaluated, and should be the focus of a new study.

The rice grain yield in the four crop seasons (Table 4) was negatively related to the larval infestation level of $O$. oryzae (Figure $1 \mathrm{~B}$ ). The grain yield was significantly higher in plots cultivated in 2010/2011 with seed treated with 10 or $30 \mathrm{~g}$ fipronil. As, in these plots, larval infestations were significantly lower in the three subsequent rice crop seasons, without the use of the insecticide, it is evident that the control effect of doses applied to seed in 2010/2011 was kept and prevented production losses.
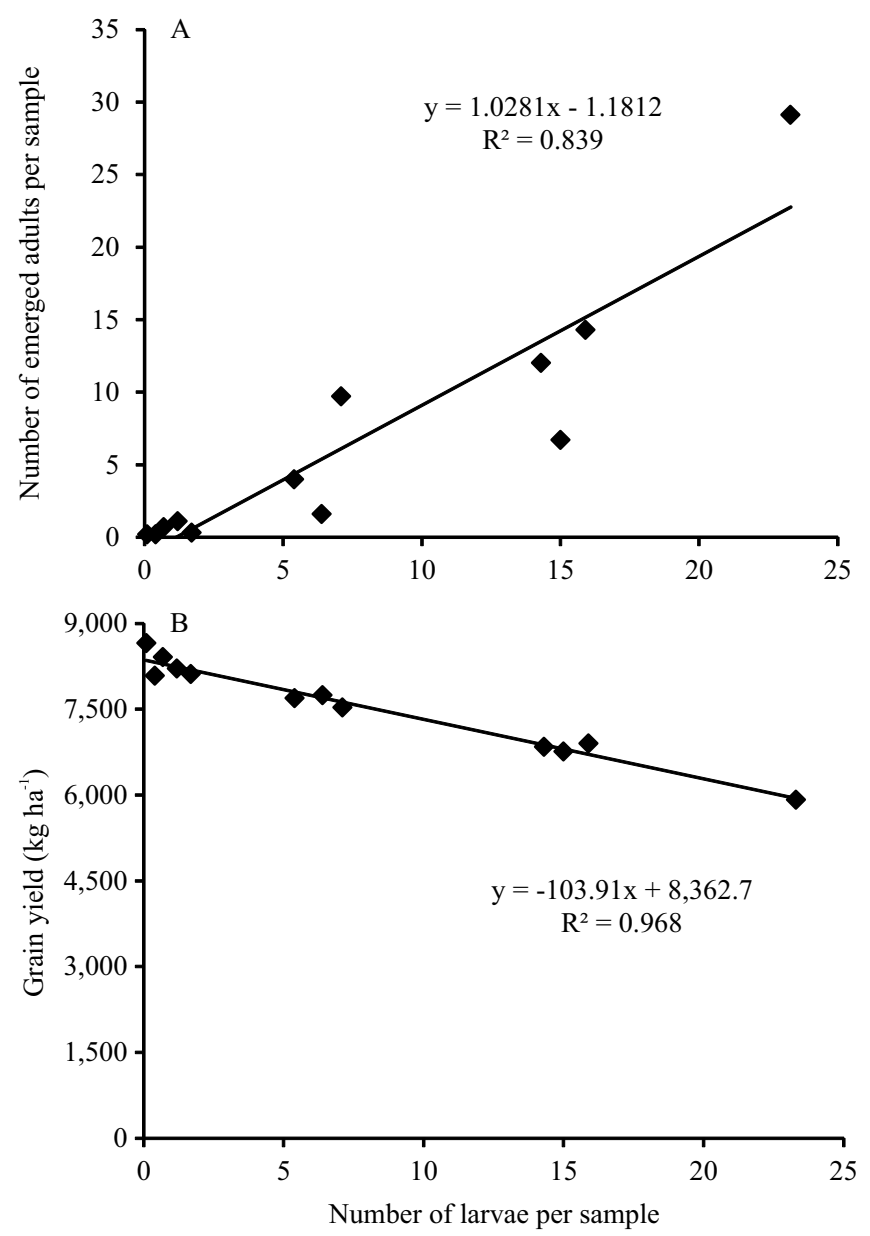

Figure 1. Emergence of Oryzophagus oryzae adults (A), and grain yield (B) in relation to larval infestation level in flooded rice plots. Mean of four crop seasons: 2010/2011, with seed treated with fipronil; and three subsequent crop seasons - 2011/2012, 2012/2013, 2013/2014 - without insecticide application.
Table 4. Mean ( \pm standard error) of grain yield $\left(\mathrm{kg} \mathrm{ha}^{-1}\right)$ in flooded rice plots, cultivated in the first crop season (2010/2011) with seed treated with fipronil for the control of Oryzophagus oryzae, and in three subsequent crop seasons without insecticide application ${ }^{(1)}$.

\begin{tabular}{|c|c|c|c|c|c|c|}
\hline \multirow[t]{2}{*}{ Treatment $^{(2)}$} & \multirow{2}{*}{$\begin{array}{c}\begin{array}{c}\text { Treated } \\
\text { seed }\end{array} \\
2010 / 11\end{array}$} & \multicolumn{5}{|c|}{ Seed and plants not treated with insecticide } \\
\hline & & $2011 / 12$ & $2012 / 13$ & 2013/14 & $\operatorname{Mean}^{(3)}$ & $\mathrm{PV}^{(4)}(\%)$ \\
\hline Control & $\begin{array}{c}6,649 \mathrm{aA} \\
( \pm 89)\end{array}$ & $\begin{array}{c}6,923 \mathrm{aA} \\
( \pm 114)\end{array}$ & $\begin{array}{c}6,413 \mathrm{aA} \\
( \pm 136)\end{array}$ & $\begin{array}{c}6,758 \mathrm{aA} \\
( \pm 95)\end{array}$ & $\begin{array}{l}6,698 \mathrm{a} \\
( \pm 113)\end{array}$ & - \\
\hline Fipronil 10 & $\begin{array}{c}8,108 \mathrm{bA} \\
( \pm 65)\end{array}$ & $\begin{array}{c}7,736 \mathrm{bA} \\
( \pm 53)\end{array}$ & $\begin{array}{c}\text { 7,817bA } \\
( \pm 198)\end{array}$ & $\begin{array}{c}7,740 \mathrm{bA} \\
( \pm 61)\end{array}$ & $\begin{array}{l}7,765 b \\
( \pm 132)\end{array}$ & 16.9 \\
\hline Fipronil 30 & $\begin{array}{c}8,158 \mathrm{bA} \\
( \pm 247)\end{array}$ & $\begin{array}{c}8,353 \mathrm{cA} \\
( \pm 142)\end{array}$ & $\begin{array}{c}8,656 \mathrm{cA} \\
( \pm 303)\end{array}$ & $\begin{array}{c}8,208 \mathrm{bA} \\
( \pm 439)\end{array}$ & $\begin{array}{l}8,406 \mathrm{c} \\
( \pm 316)\end{array}$ & 25.5 \\
\hline
\end{tabular}

${ }^{(1)}$ Means followed by equal letters, lowercase in columns and uppercase in rows, do not differ by the Scott-Knott test, at 5\% probability. ${ }^{(2)}$ Equivalent to $10 \mathrm{~g}$ (fipronil 10) and equal to $30 \mathrm{~g}$ (fipronil 30) $100 \mathrm{~kg}^{-1}$ seed. ${ }^{(3)}$ Means of crop seasons without insecticide application. ${ }^{(4)} \mathrm{PV}$, positive variation of the mean in relation to the control.

As a final remark, it is emphasized that $O$. oryzae occurs in rice fields in different soil classes (Gomes \& Magalhães Júnior, 2004), which may lead to variations of the persistence of fipronil and its metabolites (Doran et al., 2009). Thus, it is important to study the effect of fipronil residues on the insects at least in the predominant classes of soil.

\section{Conclusions}

1. The conventional management of flooded rice, in Planossolo Háplico (Typic Albaqualf), using seed treated with fipronil, causes an accumulation of insecticide residues in the soil, such as fipronil-sulfide.

2. Fipronil residues have the potential to reduce the population of $O$. oryzae and prevent rice yield losses in up to three subsequent crop seasons.

\section{Acknowledgments}

To Mr. Elton Rogério Nolasco Fonseca, employee of Embrapa Clima Temperado, whose effort to conduct the experiment in the field was essential to this work.

\section{References}

ABBOTT, W.S. A method of computing the effectiveness of an insecticide. Journal of Economic Entomology, v.18, p.265-267, 1925. DOI: $10.1093 /$ jee/18.2.265a.

ACOMPANHAMENTO DA SAFRA BRASILEIRA [DE] GRÃOS: safra 2014/15: décimo segundo levantamento, Brasília, 
DF, v.2, n.12, set. 2015. 134p. Available at: $<$ http://www.conab. gov.br/OlalaCMS/uploads/arquivos/15_09_11_08_57_48_ boletim_graos_setembro_2015.pdf $>$. Accessed on: Apr. 182016.

AGROFIT: sistema de agrotóxicos fitossanitários. Available at: $<$ http://www.agricultura.gov.br/servicos-e-sistemas/sistemas/ agrofit>. Accessed on: Aug. 32016.

AOAC INTERNATIONAL. AOAC Official Method 2007.01: pesticide residues in foods by acetonitrile extraction and partitioning with magnesium sulfate. 2007. Available at: $<$ https:// nucleus.iaea.org/fcris/methods/MRM_AOAC_2007_01.pdf $>$. Accessed on: Aug. 32016.

BEDIENT, P.B.; HORSAK, R.D.; SCHLENK, D.; RIK, M.H.; PIERSON, J.D. Environmental impact of fipronil to the Louisiana crawfish industry. Environmental Forensis, v.6, p.289-299, 2005. DOI: $10.1080 / 15275920500194530$.

BIOENSAIOS. Available at: <http://nsf-bioensaios.com.br/>. Accessed on: Aug. 82016.

BONMATIN, J.-M.; GIORIO, C.; GIROLAMI, V.; GOULSON, D.; KREUTZWEISER, D.P.; KRUPKE, C.; LIESS, M.; LONG, E.; MARZARO, M.; MITCHELL, E.A.D.; NOOME, D.A.; SIMON-DELSO, N.; TAPPARO, A. Environmental fate and exposure; neonicotinoids and fipronil. Environmental Science and Pollution Research, v.22, p.35-67, 2015. DOI: 10.1007/ s11356-014-3332-7.

COX, C. Fipronil. Journal of Pesticide Reform, v.25, p.10-15, 2005.

DORAN, G.; EBERBACH, P.; HELLIWELL, S. Sorption and degradation of fipronil in flooded anaerobic rice soils. Journal of Agricultural and Food Chemistry, v.57, p.10296-10301, 2009. DOI: $10.1021 /$ jf902644x.

EBERHARDT, D.S.; SCHIOCCHET, M.A.; NOLDIN, J.A.; KNOBLAUCH, R.; ANDRADE, A.; AGOSTINI, I.; BACHA, R.E.; MARSCHALEK, R.; RAIMONDI, J.V.; MARTINS, G.N.; WICKERT, E.; HICKEL, E.R.; PRANDO, H.F.; SCHEUERMANN, K. K.; MIURA, L. Recomendações para a produção de arroz irrigado em Santa Catarina (Sistema prégerminado). 3.ed. Florianópolis: Epagri, 2015. 92p. (Sistema de produção, 48).

FIPRONIL: new pesticide fact sheet. Washington: United States Environmental Protection Agency Office of Prevention, Pesticides and Toxic Substances, 1996. Available at: <https:// www.fluoridealert.org/wp-content/pesticides/fipronil.epa.facts. may.1996.htm>. Accessed on: Sept. 242015.

GOMES, A. da S.; MAGALHÃES JÚNIOR, A.M. de (Ed.). Arroz irrigado no Sul do Brasil. Brasília, DF: Embrapa Informação Tecnológica, 2004. 899p.

JINGUJI, H.; THUYET, D.Q.; UÉDA, T.; WATANABE, H. Effect of imidacloprid and fipronil pesticide application on Sympetrum infuscatum (Libellulidae: Odonata) larvae and adults. Paddy and Water Environment, v.11, p.277-284, 2013. DOI: 10.1007/s10333012-0317-3.

MANRIQUE, W.G.; FIGUEIREDO, M.A.P.; MACHADONETO, J.G. Dissipação e risco ambiental do fipronil no meio aquático. The Biologist, v.11, p.107-117, 2013.
MARCHESAN, E.; SARTORI, G.M.S.; AVILA, L.A. de; MACHADO, S.L. de O.; ZANELLA, R.; PRIMEL, E.G.; MACEDO, V.R.M.; MARCHEZAN, M.G. Resíduos de agrotóxicos na água de rios da Depressão Central do Estado do Rio Grande do Sul, Brasil. Ciência Rural, v.40, p.1053-1059, 2010. DOI: 10.1590/S0103-84782010005000078.

MARTINS, J.F. da S. Níveis de infestação de Oryzophagus oryzae (Costa Lima, 1936) (Coleoptera Curculionidae) durante o período de desenvolvimento da cultura do arroz. Ciência e Cultura, v.28, p.1493-1497, 1976.

MARTINS, J.F. da S.; CUNHA, U.S. Gorgulho-aquático-doarroz, Oryzophagus oryzae (Lima). In: VILELA, E.F.; ZUCCHI, R.A. (Ed.). Pragas introduzidas no Brasil: insetos e ácaros. Piracicaba: Fealq, 2015. p.624-642.

MARTINS, J.F. da S.; MELO, M.; SILVA, F.F. da; GRÜTZMACHER, A.D.; CUNHA, U.S. Novo método para aferição da densidade populacional do gorgulho-aquático em plantas de arroz irrigado. Agropecuária Clima Temperado, v.4, p.363-370, 2001.

MARTINS, J.F. da S.; ROSA, A.P.S.A. da; MATTOS, M.L.T.; THEISEN, G. Redução da dose do inseticida fipronil aplicada em sementes de arroz para o controle da bicheira-da-raiz. Pelotas: Embrapa Clima Temperado, 2010. 10p. (Embrapa Clima Temperado. Circular técnica, 309).

MATTOS, M.L.T.; MARTINS, J.F. da S.; NUNES, C.D.M.; MOURA NETO, F.P.; MAGALHÃES JUNIOR, A.; PETRINI, J.A.; SANTOS, I.B. dos. Monitoramento de agrotóxicos em áreas piloto da produção integrada de arroz irrigado na planície costeira externa e fronteira oeste do Rio Grande do Sul. Pelotas: Embrapa Clima Temperado, 2008. 4p. (Embrapa Clima Temperado. Comunicado técnico, 197).

MIELITZ, L.R.; BECKER, M.; ROMANOWSKI, H.P. Hibernation dynamics of Oryzophagus oryzae and its implications for management. Entomologia Experimentalis et Applicata, v.78, p.159-166, 1996. DOI: 10.1111/j.1570-7458.1996.tb00777.x.

NEVES, M.B. das; MARTINS, J.F. da S.; GRÜTZMACHER, A.D.; LIMA, C.A.B. de; BÜTTOW, G.T. Profundidade da amostragem de solo e de raízes e índice de infestação de Oryzophagus oryzae (Costa Lima, 1936) (Coleoptera: Curculionidae) em cultivares de arroz. Ciência Rural, v.41, p.2039-2044, 2011. DOI: 10.1590/ S0103-84782011001200001.

NGIM, K.K.; CROSBY, D.G. Abiotic processes influencing fipronil and desthiofipronil dissipation in California, USA, rice fields. Environmental Toxicology and Chemistry, v.20, p.972977, 2001. DOI: 10.1002/etc.5620200506.

RAVETON, M.; AAJOUD, A.; WILLISON, J.; CHERIFI, M.; TISSUT, M.; RAVANEL, P. Soil distribution of fipronil and its metabolites originating from a seed-coated formulation. Chemosphere, v.69, p.1124-1129, 2007.

SCHLENK, D.; HUGGETT, D.B.; ALLGOOD, J.; BENNETT, E.; RIMOLDI, J.; BEELER, A.B.; BLOCK, D.; HOLDER, A.W.; HOVINGA, R.; BEDIENT, P. Toxicity of fipronil and its degradation products to Procambarus sp.: field and laboratory studies. Archives of Environmental Contamination and Toxicology, v.41, p.325-332, 2001. DOI: 10.1007/s002440010255. 
SILVA, F. de A.S. e; AZEVEDO, C.A.V. de. Versão do programa computacional Assistat para o sistema operacional Windows. Revista Brasileira de Produtos Agroindustriais, v.4, p.71-78, 2002. DOI: 10.15871/1517-8595/rbpa.v4n1p71-78.
TINGLE, C.C.D.; ROTHER, J.A.; DEWHURST, C.F.; LAUER, S.; KING, W.J. Health and environmental effects of fipronil. London: Pesticide Action Network, 2000. 30p. (Briefing paper).

$\overline{\text { Received on December 7, } 2015 \text { and accepted on August 12, } 2016}$ 